\title{
Impact of Employee Stock Ownership Plans on Productivity in Video Game Companies
}

\author{
RAFAŁ ŁABĘDZKI \\ Instytut Kapitału Ludzkiego \\ SGH Warsaw School of Economics \\ Al. Niepodległości 162 02-554 Warsaw \\ POLAND \\ PRZEMYSŁAW GADOMSKI \\ Greenlite Media and Greenlite Embedded Systems \\ ul. Osmanska 11 02-823 Warsaw \\ POLAND \\ PAWEŁ MULTANIAK \\ FIGURES Kancelaria Rachunkowa \\ ul. Towarowa 35 61-896 Poznań \\ POLAND
}

\begin{abstract}
The article deals with the importance of ESOPs (employee stock option plan) for the motivation of key employees of companies producing and publishing computer games. The conducted literature review led to the identification of a motivation model that explains how ESOPs can affect the motivation of employees in this industry. An analysis of the available studies on the importance of ESOPs for employee motivation

revealed the existence of at least one key success factor of ESOPs_psychological ownership. The empirical study includes an ESOP analysis of five computer game companies listed on the Warsaw Stock Exchange in terms of changes in the dynamics of employee productivity caused by an ESOP. One of the most important discoveries is the relationship between productivity and the structure of the ESOP, in particular the percentage of company shares that were offered to its participants.
\end{abstract}

Key-Words: ESOP, hcm, video game industry, motivation, motivation model, human capital

Received: December 20, 2020. Revised: August 7, 2021. Accepted: August 14, 2020. Published: September 2, 2021.

\section{Introduction}

Since 1971, when the video game industry began, games have evolved from a simple, multipixel form of Computer Space developed by Atari [1] to virtual universes gathering millions of players around the world [2]. This evolution is certainly going to continue, as in the video game industry innovations never stop, a good example of which are the metaverses, built on a state-of-the-art blockchain technology of non-fungible tokens.

With revenues of nearly $\$ 160$ billion in 2020 [3], the video game industry already surpassed the music industry, whose market was only $\$ 20$ billion in 2019. It is projected, that by 2023 the video game industry market size will reach $\$ 200$ billion [3], which means almost a 10\% year-to-year growth rate. As a good comparison, the gross domestic product of Hungary equaled $\$ 160$ billion in 2021.

The gaming industry is not only big in terms of its revenue value but also in terms of employment. In the United States of America alone, nearly 250,000 people were employed in this industry in 2020 , which means this number has doubled in the past 10 years. Revenue per employee in 2019 in the US gaming industry equaled $\$ 140,000$ [4]. In Canada, the industry employed about 5,000 people in 2005, with revenue per employee of approximately $\$ 90,000$ [5]. In Poland, 9,710 people worked in the video game industry in 2020 , with revenue per employee of approximately $\$ 60,000$ [6]. Dividing the global video game market value in 2020 of $\$ 160$ billion by the US revenue per 
employee $(\$ 140,000)$ and the Polish revenue per employee $(\$ 60,000)$, it can be estimated that globally the video game industry employs from about 1.14 million to 2.67 million people.

The numbers mentioned above indicate that the video game industry is an important part of the global entertainment market and also a workplace for millions of people around the world. With this in mind, research was conducted with the aim of establishing the impact of employee stock ownership plans (ESOPs) on the performance of companies from the video game industry. The following research questions were formulated:

1. What motivates employees in the video game industry?

2. Can ESOPs increase the motivation of employees in video game companies?

3. What is the impact of ESOPs on the performance of video game companies?

To answer the first question, a study of the literature on the subject was conducted, covering mainly English sources. Scientific papers regarding the motivation of employees in the IT sector, ESOPs, and models of psychological ownership were studied.

An empirical study was conducted to answer the second and the third question. Financial reports from video game companies listed on the Warsaw Stock Exchange (WSE) were analyzed to assess the effects of an ESOP on the financial performance of the company.

It is worth mentioning that the video game industry in Poland has been blossoming since the global success of CD Projekt's video game The Witcher 2 in 2011. Over the last decade, dozens of game studios have undergone IPOs on the main floor of the WSE or the alternative market NewConnect. On 3 April 2020, CD Projekt became the highest valued company of the WSE at 27.77 billion PLN (\$9.9 billion), overtaking the largest state-owned bank PKO BP.

The paper comprises six sections. The most recent research results on motivation in the IT industry are presented in the literature review section. Conclusions from the literature review led to the formulation of the research model and research tool, described in the method section. Results of the empirical research are described in the following section. In the discussion Findings from both the literature review and the empirical research are presented and discussed. Conclusions are presented in the last section.

\section{Literature Review}

The study of the literature showed that the introduction of an ESOP to a company on average rarely increases the business performance of the company. Therefore, one may be tempted to state that ESOPs are not beneficial for companies (and their shareholders) but only to those who receive the actual benefits of ESOPs (typically executives and top management). On the other hand, one may arrive at a conclusion that only well designed, targeted, and managed ESOPs will have a chance to offer benefits to a company through its positive impact on the employees' motivation. This leads to the conclusion that the structure of an ESOP, its design, and execution in relation to a particular company determines the potential success or failure of an ESOP.

With regard to the video game industry, which shares common features with the IT and entertainment industries, an analysis was conducted, covering a literature about the motivation and motivation models in IT, ESOPs impact on companies performance and Psychological Ownership theory.

\subsection{Motivators for Engineers in the IT Industry}

In the recent past, extensive reviews of the literature on motivation in the IT industry were made Sharp et al. and Beecham et al. [7, 8]. Reviews covered the subject of motivation in software development companies.

According to Sharp et al. [8], identification with the task is the key motivator for software engineers. This means that employees need to know what they have to do and what is the purpose of the certain assignment to assess whether they have a personal interest in it. Only with this personal interest can the identification with the task can occur, which then results in the employee's motivation. The important role of employee participation, involvement, and working with others with respect to motivation indicates that not only do software engineers want to understand the reason and purpose of their tasks, but they would also prefer to take part in the decision-making process and work in a team rather than only by themselves. The latter stresses the need for specialization and task distribution according to the team members' competences. It also implies the need for good management, especially in terms of the team building and communication. This should be delivered with the support of the senior management. According to Schmid and Adams [9], 
employees are demotivated if they don't get enough support from the senior management, regardless of the type of organizational structure of the company. The Career path should be considered as the opportunity for advancement, promotion prospects, and career planning [8]. This is one of the most challenging motivators to achieve in project-oriented organizations like the ones which focus on video game development and publishing, as by definition a project has to have a timely defined end, which results in the dissolvement of the team [10]. With regard to ESOPs, other key motivators for software engineers could be the sense of belonging, empowerment and responsibility, and equity and financial stability of the company [8].

Table 1. What motivates software engineers?

\begin{tabular}{lr}
\hline Motivators of software engineers & $\begin{array}{r}\text { Number of } \\
\text { studies } \\
\text { reporting }\end{array}$ \\
\hline Identify with the task & 20 \\
Employee participation/ & 16 \\
involvement/working with others & \\
Good management & 16 \\
Career path & 15 \\
Variety of work & 14 \\
Sense of belonging/supportive & 14 \\
relationships & \\
Rewards and incentives & 14 \\
Recognition & 12 \\
Development needs addressed & 11 \\
Technically challenging work & 11 \\
Job security/stable environment & 10 \\
Feedback & 10
\end{tabular}

Autonomy 9

Work-life balance $\quad 7$

Making a contribution/task 6

significance (impact on lives or

work of other people)

Empowerment/responsibility 6

Appropriate working 6

conditions/environment/

equipment/tools/physical

space/quiet

Trust respect 4

Equity 3

Working in a company that is 2 successful

Sufficient resources

2

Note. From [8.35]

Employee motivation affects: retention, productivity, project delivery time, budgets, absenteeism, and project success. Retention is the most represented effect in the literature [8]

\subsection{Motivation Models for Engineers in the IT Industry}

The most important models of motivation in software engineering are (1) the job characteristic model (JCM), with its extensions proposed by Hackham and Oldham in 1975; (2) the group of models focusing on software engineer job satisfaction; (3) models of leadership influence on software engineers` motivation; and (4) models of open-source developer software engineers` motivation $[7,8]$. 


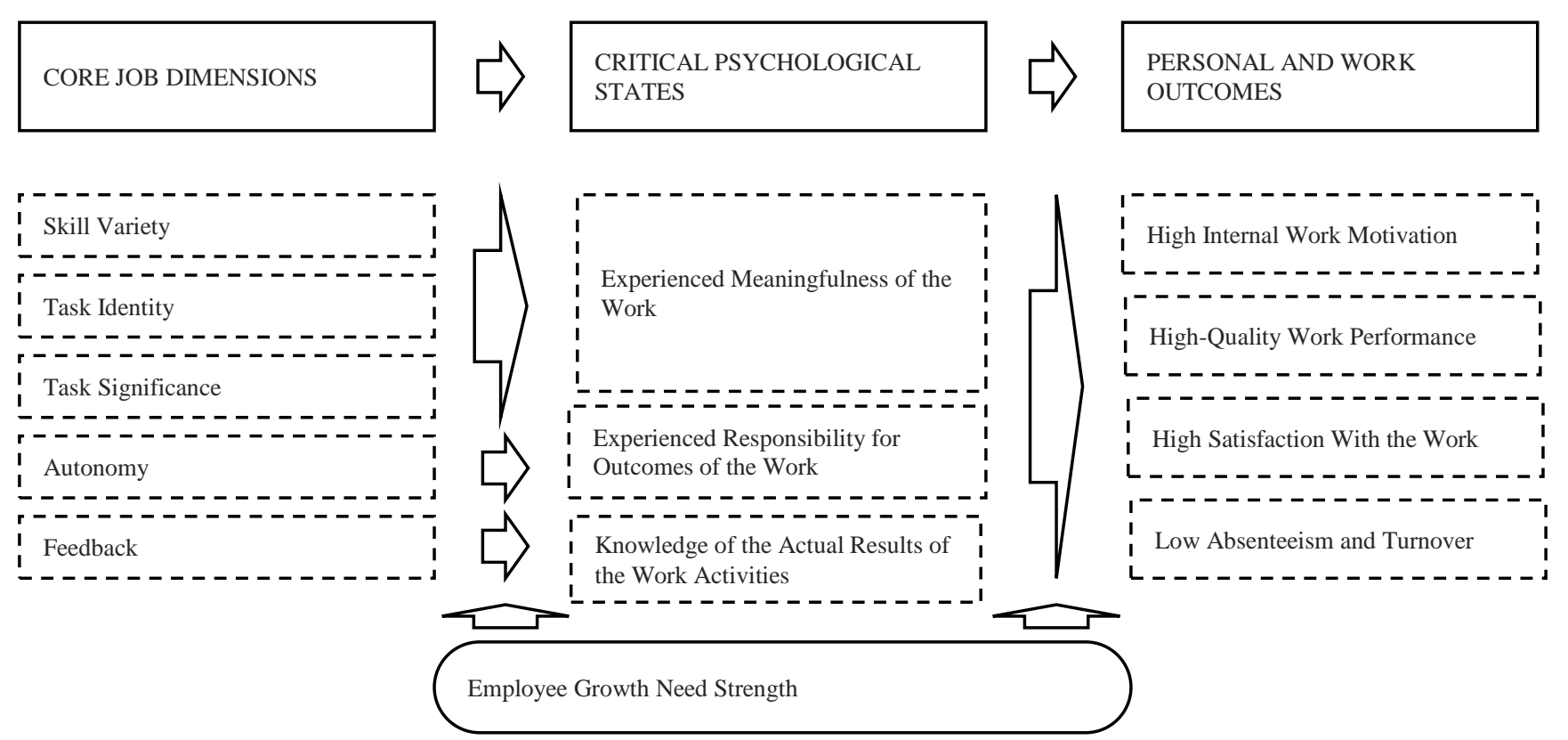

Fig.1: JCM of work motivation. Note. From [11].

Among all motivation models, JCM seems to be the most important. It assumes that the job can be described in five core job dimensions: (1) skill variety, (2) task identity, (3) task significance, (4) autonomy, and (5) feedback. The composition of dimensions causes or affects critical psychological states, which are (1) experienced meaningfulness of the work, (2) experienced responsibility for outcomes of the work, and (3) knowledge of the actual results of the work activities. These states can result in personal and work outcomes, such as the following: (1) high internal work motivation, (2) high-quality work performance, (3) high satisfaction with the work, and (4) low absenteeism and turnover. The strength of the relation between core job dimensions, critical psychological states, and outcomes depends on the employee growth need strength (GNS). To assess the job's potential to cause critical psychological states, a motivating potential score (MPS) can be calculated. To make the calculation, the average score for skill variety, task identity, and task significance has to be multiplied by the score of autonomy and then multiplied by the score of feedback. The higher the MPS, the more probable are personal and work outcomes [11].
The authors of the JCM reviewed their original model from the 1970s and concluded that contemporary organizations define jobs differently than in the past. More stress should be put on teamwork and social aspects of job design. This is why currently the JCM is considered more like a solid foundation for the modified or extended models rather than an accurate model itself [12].

The valuable addition to the JCM, which is in line with the mentioned argumentation of Oldham and Hackman [12], was made by Couger and Zawacki, based on their research of MIS Managers in 1979. Research conducted with the survey instrument called the job diagnostic survey for data processing (JDS/DP) revealed the relations between MPS and GNS and added a new factor of social need strength (SNS) [13.9] as a second mediator between core job dimensions and critical psychological states and personal and work outcomes [14]. Moreover, satisfaction with work was broken down into three dimensions: general satisfaction, satisfaction with supervision, and satisfaction with pay. Also, the core job dimensions set was extended with goal setting and organizational climate. The final model with the additions described above is presented in Fig. 2, after [8]. 

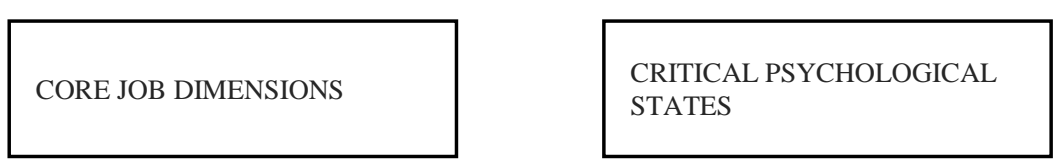

PERSONAL AND WORK OUTCOMES

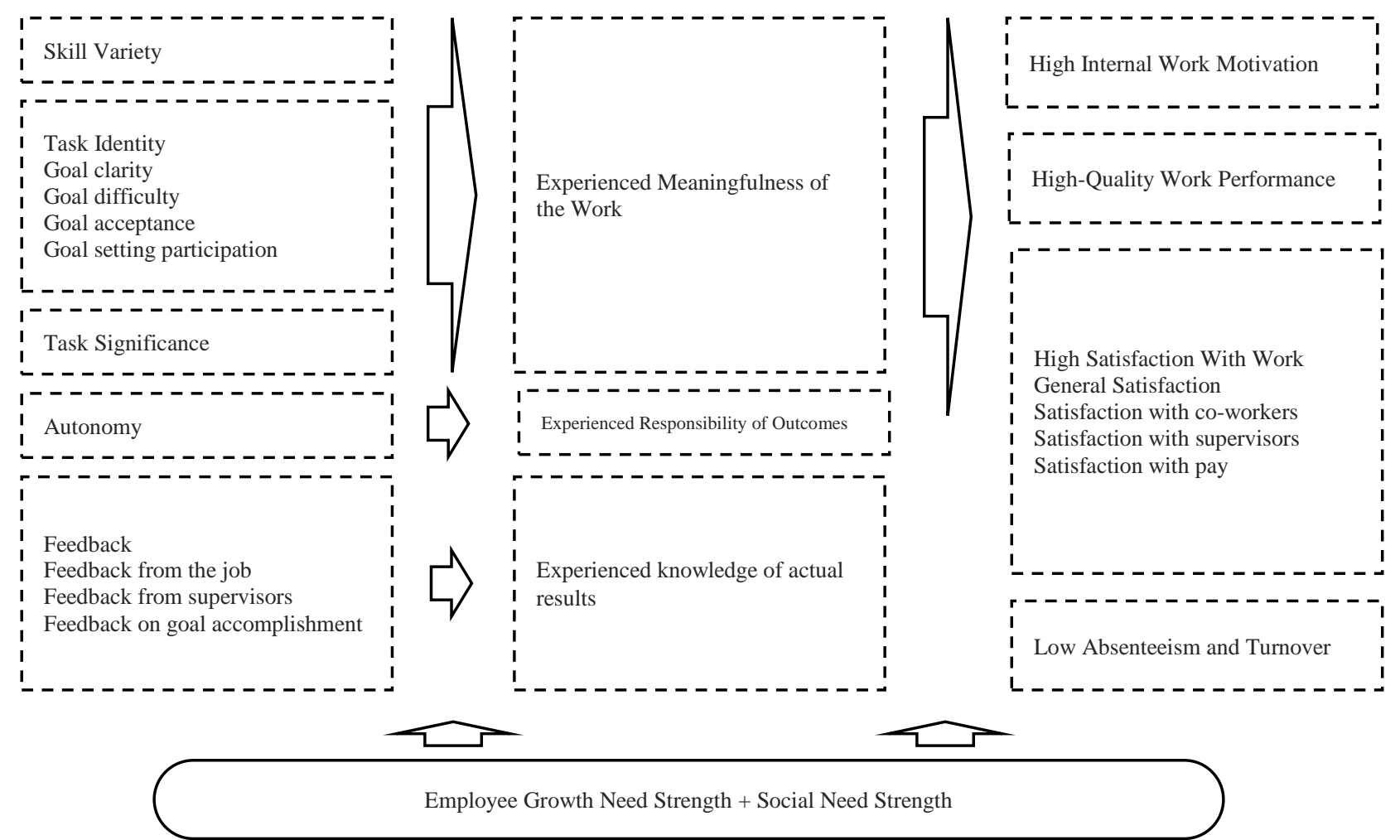

Fig.2: JCM extended by Cougar and Zawack. Note. From [8].

Among other modifications of the JCM, the work of Pierce et al. [15] on the psychological ownership within the job design context is of the great importance with regard to the ESOP's theoretical structure. According to Pierce et al., core job dimensions lead to the "routes to" psychological ownership and then to the psychological ownership of the job, which is the critical psychological state in the revised JCM. The revised model also replaces the original personal and work outcomes with the ones originating from the psychological ownership theory [15]. 

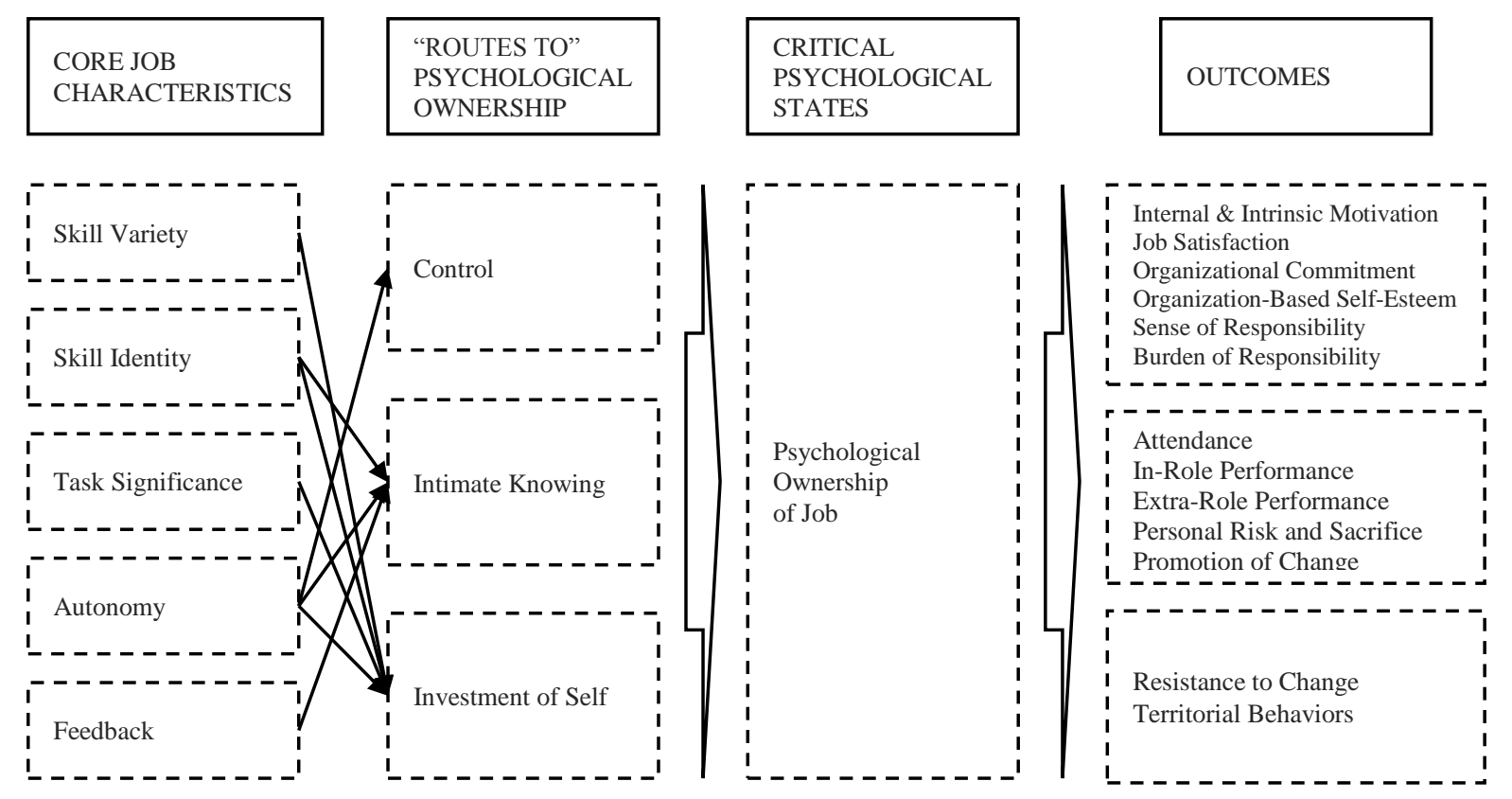

Fig.3: A psychological ownership-based revision of the JCM. Note. From [15].

Psychological ownership seems to be an important organizational phenomenon with a significant impact on an organization's performance. It is based on the psychology of possession. Ownership can be experienced towards an object but also felt toward ideas, artistic creations, and other people. Feelings of ownership are part of the human condition. People develop feelings of ownership toward a variety of objects, which have important behavioral, emotional, and psychological consequences. The target of those feelings becomes part of the psychological owner's identity. The roots of psychological ownership can be found in three main motives: (1) efficacy and effectance, (2) self-identity, and (3) "having a place". For psychological ownership to emerge, three interrelated routes have to be explored: 1) the first one is the control over the target, which can be exercised, for example, by the job design, as in the $\mathrm{JCM} ; 2)$ the second route is to intimately know the target, which can be achieved by learning information crucial for the company's operations, like goals or performance; and 3) the third route is investing the self into the target, which can mean investing time, ideas, skills, and physical, psychological and intellectual energies. Pierce et al. propose that (1) there is a positive and casual relationship between the amount of control an employee has over a particular organizational factor and the degree of ownership the employee feels toward that factor, (2) there is a positive and casual relationship between the extent to which an employee intimately knows a particular organizational factor and the degree of ownership the employee feels toward that factor, and (3) there is a positive and casual relationship between the extent to which an individual employee invests himself or herself into the potential target of ownership and the degree of ownership the employee feels toward that target. Effects of psychological ownership can be both positive and negative for the organization [16]. As depicted in Fig. 3, expected outcomes are the following: (1) internal and intrinsic motivation, (2) job satisfaction, (3) organizational commitment, (4) organization-based self-esteem, (5) sense of responsibility, (6) burden of responsibility, (7) attendance, (8) in-role performance, (9) extra-role behaviors, (10) personal risk and sacrifice, (11) promotion of change, (12) resistance to change, and (13) territorial behaviors [15.19].

The literature review on motivation in the IT industry shows that the JCM with its modifications is a valid motivation model for the analysis of contemporary organizations. Inclusion of psychological ownership into the JCM created a possible link to the ESOP's theoretical framework, which assumes that the positive effect of the company co-ownership is mediated by psychological ownership.

\subsection{Employee Ownership's Impact on Companies` Performance}

Psychological ownership can be achieved not only by the adjustment of core job dimensions, as described in the extended JCM in Fig. 3, but also, 
according to the ESOP theoretical framework, by employee ownership (EO) [16]. As depicted in Fig. 4, EO of some form (for example ESOP) leads to certain individual outcomes (affective/attitudinal, motivational, behavioral responses) either directly or indirectly through operationalized ownership and psychological ownership. For the latter to emerge not only the formal ownership has to be established. As Pierce et al. [16] propose, certain preconditions have to be met with regard to (1) management's philosophical commitment to EO,
(2) ownership expectations (regarding equity, influence, information), (3) perceived legitimacy of ownership (regarding equity, influence, information), 4) investment orientation, and 5) type of ownership plan and context of origin. What seem to be a significant element of the model are the expected group outcomes (cooperative behaviors, work group norms, peer pressure) available only through the PO [16].

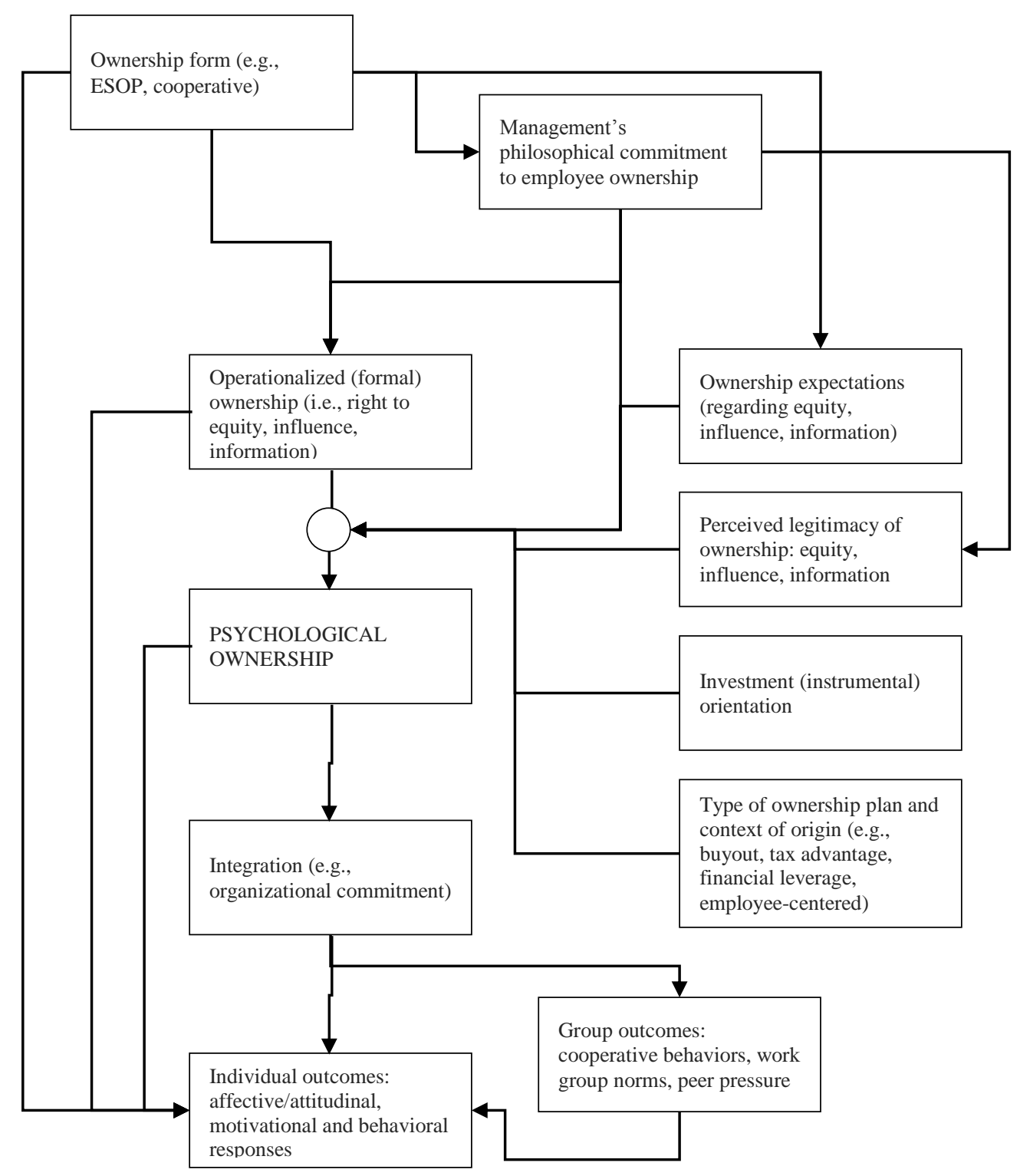

Fig.4: A model of EO. Note. From [16].

The crucial role of the management's philosophical commitment to EO is supported by the studies of Long [17] and Rosen and Quarrey [18], which revealed that the lack of managerial commitment to EO prevents it from producing its intended results. This corresponds with the notion that perceived ownership is more important than 
formal ownership [19] in terms of creating positive organizational effects.

Studies on ESOPs have produced diverse results. Part of them [20, 21, 22., 23., 24] show ESOPs` positive effects on company performance, and the other part indicates no correlation [25, 26]. Only one study was found showing that the cost of ESOP introduction was higher than profit achieved [27].

Studies from companies partially related to the video game industry (Huawei Technologies Co. Ltd., Eircom Ltd., Rocket Inc.) also show diverse results [24, 28, 29]. A closer examination of the mentioned studies reveals the reasons for the diversification of ESOPs' impact on companies, which implemented them.

In the case of Eircom Ltd., the Irish telecom, the introduction of an ESOP decreased the perceived level of participation in decision-making. Despite holding a substantial part of the company's shares (35\%), no voting rights for election of the board of directors members were given to ESOP participants. Moreover, ESOP participation was also allowed after the leave from the company, which resulted in more than $50 \%$ of ESOP participants being outside the company's structure. As a result, the ESOP in Eircom did not create psychological ownership effects and changes in labor productivity (LP) [29].

An interesting case of financial ownership overshadowing psychological ownership was observed in Rocket Inc. As stated in the study of Welch [24], the turnover among employees in the company was very low (a positive effect of the ESOP) only until the stock price was rising. After a substantial drop, many employees left. What is more, before the stock's plummet, low turnover did not result in high LP. Employees were more interested in becoming rich due to the rising value of their stocks than in improving the company performance. There was however a small group of "old-timers", who built the company and felt responsibility for its success beyond the stock's price [24].

Huawei Technologies Co. Ltd. (Huawei) is an example of a $100 \%$ employee-owned company. The ESOP in Huawei underwent three major stages from 1990 when it was created, to 1997 when it was modified for the first time, to 2001 when the former ESOP model was transformed into virtual stock options. Although the research did not consider psychological ownership as a factor for fostering EO effects on the company's performance, a model including motivation, commitment, and turnover reduction was adopted for the research framework. Results of the introduction of an ESOP in Huawei were positive in terms of LP and assets productivity (AP). The reasons for the ESOP's success were arguably employees` full ownership of the company, resulting in decision-making participation and financial incentives, as each year ESOP participants received dividends [28].

The studies on an ESOP's impact on company performance led to the conclusion that a balance between formal ownership, resulting in financial incentives, and psychological ownership has to be maintained to deliver expected EO results. According to Pierce et al.'s [16] EO model, this means that for EO success not only is the ESOP structure itself important but also its introduction with respect to management's philosophical commitment to EO, resulting in perceived legitimacy of ownership, ownership expectations, and investment orientation.

\section{Method}

\subsection{The Model of Motivation for the Video Game Industry}

As there is no model of motivation dedicated for the video game industry, it is justified to propose a construct, which can be tested and modified to meet the industry's specific features. The literature review on motivation in the IT industry, which seems to be the closest to the video game industry, led to the conclusion that the modified JCM is the best available theoretical framework to describe the motivation model for software developers. However, the emergence of psychological ownership theory, its input in the JCM evolution, and ESOPs' popularity allow to conclude that an adjusted motivation model can be proposed and tested in video game companies. 

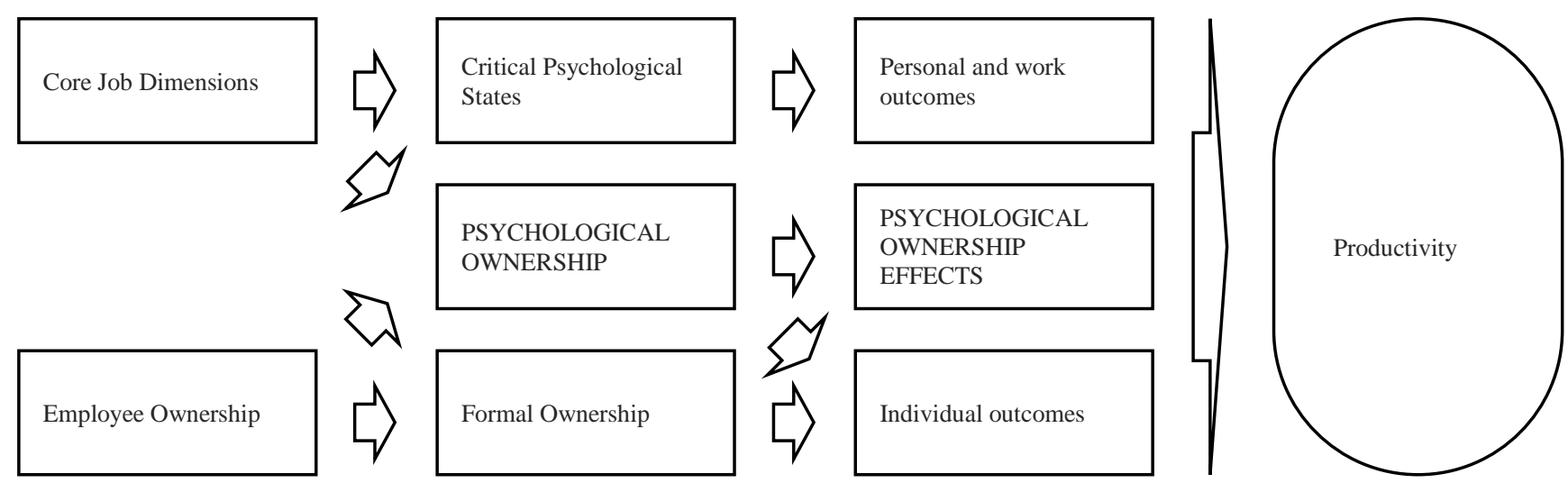

Fig.5: Model of motivation for the video game industry.

The model of motivation for the video game industry joins core job dimensions and EO in one framework. This framework assumes that there are individual paths of influence on the company's productivity for both core job dimensions and EO and one shared path through psychological ownership.

The first path leads from Core Job Dimensions, through Critical Psychological States to Personal and work outcomes. This path corresponds to the JCM extended by Cougar and Zawacki. A proper research tool for this path is a job diagnostic survey for data processing (JDS/DP) used by Cougar and Zawacki [8]. Result of the study of this path should be an assessment of importance of core job dimensions for personal and work outcomes in the video game industry.

The second path leads from Core Job Dimensions, through Psychological Ownership to Psychological Ownership Effects. This path corresponds to the psychological ownership-based revision of the JCM proposed by Pierce et al. [15]. This path is shared with the second possible starting point in the model, which is Employee Ownership. This starting point stems from the model of Employee Ownership proposed by Pierce et al. [16], which assumes that ownership in the form of e.g. ESOP cand lead to Psychological Ownership and, as an effect, to certain individual outcomes. They can be achieved by the sole Formal Ownership, which is placed in the third path of the model.

The model assumes that all paths should have an impact on labor productivity, which enables to use research tool proposed by Zhu et al. [28] and McCarthy and Palcic [29] to measure mentioned effects. In the research covered by this paper only paths starting from Employee Ownership were studied and only with ESOP as the Employee Ownership form.

\subsection{Research Tool}

To test the model, a research tool was used, which was previously proposed and used by Zhu et al. [28] in the Huawei ESOP analysis and by McCarthy and Palcic [29] in the Eircom ESOP analysis. The tool measures the dynamics of LP and AP prior and post ESOP. LP is the product of dividing annual revenue by the number of employees. AP is the product of dividing annual revenue by the value of assets.

This tool, however, doesn't show if the LP changes are stronger or weaker than AP changes, which seems to be crucial to assess the real effects of ESOP on labor. This is why an additional, innovative measure was used, a relation of the LP dynamics to AP dynamics (Labor to Assets Productivity Dynamics, LtAPD). LtAPD equals LP dynamics/AP dynamics. The interpretation is as follows: 1) if the LtAPD value is greater than 1, it means that LP grew faster than AP; 2) if the LtAPD value is lower than 1, it means that LP grew slower than AP. As ESOPs are focused on the employees` motivation, their successful implementation should result in values greater than 1, meaning that the growth of LP is stronger than of AP, or the decrease of LP is weaker than of AP

This is an innovative approach, as it captures effects of ESOP on labor productivity in relation to asset productivity, which may change or fluctuate over time because of other, external factors. Let's assume that investors received information (in annual financial statement) that labor productivity of a company grew 5 percent in one year after ESOP introduction. It is obviously a positive signal, but not very informative. Natural question that would arise is how other production factors (apart from labor) behaved in the same period. Did the asset productivity also grow by 5 percent? Or did it fall or maybe grow by less than 5 percent? Rational investor would expect that company 
would put its own resources to most productive means. So if in the same period after ESOP introduction asset productivity grew more than labor productivity (resulting in LtAPD lower than 1), then investor would evaluate ESOP rather as a failure and expect company to invest more in assets. Therefore, LtAPD is a unique measure of ESOP impact on company from shareholders or equity analyst perspective. Firstly, it gives an answer for a blunt question oft-asked during shareholders meeting - "Was all this ESOP thing worth all the effort and money company put it into?" Secondly, if ESOP is formally executed and new shares are distributed then LtAPD value becomes a universal measure allowing for assessment of ESOP's impact on company performance. Too often it happens that ESOPs are criticized for being just means of extra remuneration for few directors or officers. Also, too large ESOPs that did not bring promised longterm effects may infuriate investors that were diluted.

The empirical study covered the analysis of documents issued by five WSE-listed video game industry companies: CD Projekt (WSE ticker: CDR), BoomBit (BBT), Ten Square Games (TEN), 11bit Studios (11B), and CI Games (CIG). All of the studied companies introduced ESOPs. In the case of CD Projekt, two ESOPs were analyzed - of 2011 and 2016. In the case of 11bit Studios also two ESOPS — of 2014 and 2017-were analyzed.

ESOPs were categorized according to the following fundamental criteria: (1) size of ESOP in relation to fully diluted shares outstanding at the date of the ESOP's introduction, (2) number of persons included in the ESOP, and (3) formal criteria that foster or hinder ESOP participation including lock-ups and financing.

Employment-related and financial data were gathered, such as earnings, number of fully diluted shares outstanding, value of total assets from financial statements, and consolidated financial statements (where applicable) of every company for every year throughout the ESOPs' duration. In three cases (CD Projekt, 11bit Studios, CI Games), periods before the ESOP's introduction were also added. One of the challenges concerning data was the calculation of true employment. For the purpose of this research, employment includes all persons bound to the company on the basis of (1) an employment contract, (2) a civil contract, and (3) service agreements by self-employed persons. Such an approach is in line with Regulation (EU) 2017/1129 of the European Parliament and of the Council of 14 June 2017 on the prospectus to be published when securities are offered to the public or admitted to trading on a regulated market, and repealing Directive 2003/71/EC (Regulation (EU) 2017/1129 of the European Parliament and of the Council of 14 June 2017 on the prospectus to be published when securities are offered to the public or admitted to trading on a regulated market, and repealing Directive 2003/71/EC, 2017).

On the other hand, companies have not been obliged to reveal in financial statements the numbers of service agreement by self-employed persons and the numbers of those working for the company on civil contracts, as opposed to employment contracts. Therefore, in regards to BoomBit and Ten Square Games, data from respective prospectuses were used that were filed with the Polish Financial Supervision Authority. They were confirmed with information and estimations from the annual management reports of both companies. Hypothetical differences or inaccuracies stemming from this fact are not very significant, as the analysis of WSE-listed, stable companies far from any reorganization. Nevertheless, it should be pointed out that this relates to the important data-related difficulties that would have obfuscated the whole picture if the study had been intended to be extended to some smaller companies (e.g., non WSE-listed) or those undergoing a process of, for example, change or reorganization.

\section{Results}

The analysis of the documents issued by companies, which were the subject of this research, revealed a substantial difference between their ESOPs' structure as well as its impact on productivity (LP, AP).

\subsection{Projekt}

CD Projekt is Warsaw-based game development studio with international acclaim thanks to its trilogy The Witcher, released on 26 Oct 2007, 17 May 2011 and 18 May 2015, respectively. Its newest production, Cyberpunk 2077, had its global launch on 10 December 2020. The company has been publicly listed on WSE since 2011. CD Projekt's ESOP of 2011 [Resolution No 3 of Shareholders' Meeting of 16 December 2011] [30] was dedicated to key persons of the parent company CD Projekt and companies from CD Projekt's capital group, selected by the management board of CD Projekt. In relation to the management board members, all responsibilities 
and decisions are taken by supervisory board, whose members do not take part in the ESOP. The ESOP has two goals: to increase financial performance $(80 \%)$ and to increase long-term company value (20\%), both of which may be fostered through close ties between ESOP participants and the company.

The increase of long-term company value is defined as an increase of more than $1 \%$ higher than the increase of the WSE's main index WIG throughout the period of the ESOP, that is until 31 December 2015. Long-term company value is linked to the value of aggregated earnings per share (EPS) for years 2012-2014 equal or greater than 1,866 PLN. If this goal is not reached by 31 December 2014, then a new goal for the period 2012-2015 is set, equaling 2,436 PLN. If earning goals are only partially reached, if they are $80 \%$ or higher, then the ESOP participant receives the full amount of the ESOP minus the double percentage amount by which it missed $100 \%$.

Specific ESOP conditions may limit participation in the ESOP only to those individuals who are in the company ("loyalty criterion"). The ESOP's duration is 4 years, that is 2012-2015. Valuation of this ESOP on 31 December 2012 was 551,000 PLN, while in 2015, it reached 23.3 million PLN. The ESOP was presented in a financial statement according to International Financial Reporting Standard 2 Share-based payment.

CD Projekt's 2016 ESOP [Resolutions No 20 and No 21 of Shareholders' Meeting of 24 May 2016] [31] was very similar to its successful 2011 version. It also included both stock-exchangerelated goals (20\%) and company financial performance goals (80\%). Stock-exchange-related goals were identically defined as in 2011 but in relation to the period 2016-2021. Financial goals were defined as aggregated earnings, equal to 618.4 million PLN in 2016-2019, 855.5 million PLN in 2016-2020, and 1,092.6 million PLN in 20162021. There is also a discount in share price for ESOP participants of $13.1 \%$ if financial goals are reached faster. ESOP shares are subject to a oneyear lock-up. Despite controversies and technical difficulties with the studio's newest production, Cyberpunk 2077, the company managed to reach both goals and the ESOP was executed and presented in a financial statement for 2020, published on 22 April 2021.

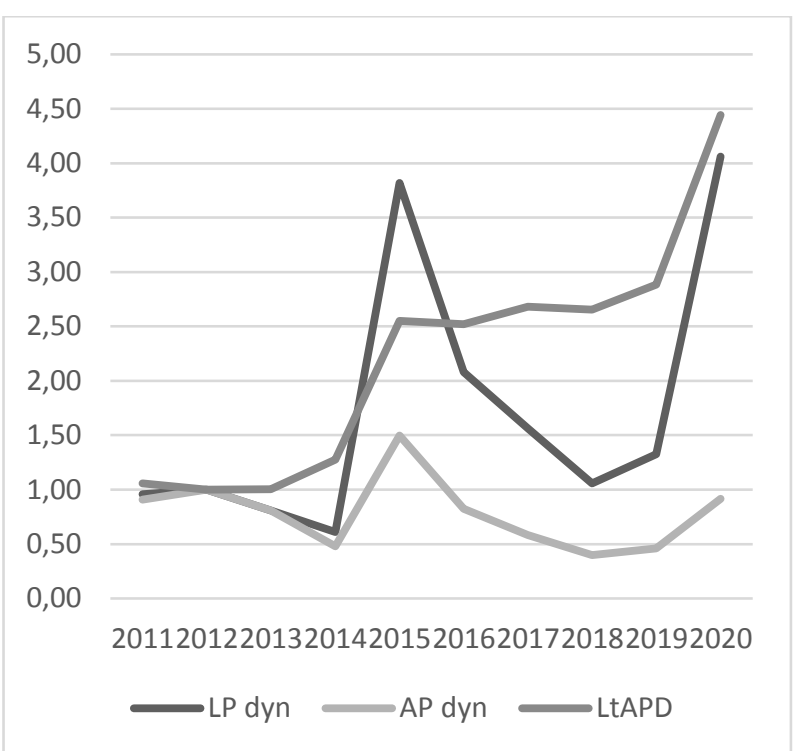

Fig.6: LP and AP dynamics in CD Projekt. Note. CD Projekt's Financial Statement 2011-2020 [32].

After 8 years of the ESOP, LP grew by approximately $400 \%$, and AP remained almost unchanged. Because of this difference in dynamics between both types of productivity, it is possible that the ESOP was one of the factors behind LP growth, as an ESOP aims to increase the motivation of employees.

\subsection{1bit Studios}

11 bit Studios is also Warsaw-based gaming company founded in 2010. Two of its most successful productions include This War of Mine, released in 2014, and Frostpunk, released in 2018. The company has been publicly listed since 2011 . 11 bit Studio's ESOP of 2014 [Resolutions No 5$10 / 06 / 2014$ of Shareholders' Meeting of 27 June 2014] [33] was dedicated to the management board and high-level employees and selected contractors. The ESOP duration was 2014-2016, while potential shares could be taken by beneficiaries until 30 June 2020. Such a long period of timethree years - for employees to decide whether or not to take shares is favorable for beneficiaries, as they have quite a lot of time to organize their own financing for share purchases.

There are five ESOP goals-all financial. They consist of (1) gross revenue of the capital group, (2) gross earning of the capital group, (3) gross revenue of the company's subsidiary, (4) gross earning of the company's subsidiary, and (5) the revenue of the publishing division of the company. If financial goals are not met, then the ESOP value will be diminished by $10 \%$ for every $5 \%$ of the goal that has not been met. There was a fixed price for 
one share in the ESOP at 8.59 PLN. At the date of the ESOP's introduction (27 June 2014), the stock price was 12.85 PLN, which included a $33 \%$ discount. The ESOP was executed, and the company valued it at $584 \mathrm{k}$ PLN. The market price of 11bit Studio's shares in December 2016 oscillated around 146-147 PLN. Following the successful ESOP, the company on 10 May 2017 [Resolutions No 18-23/05/2017 of Shareholders' Meeting of 10 May 2017] [34] introduced an ESOP for the years 2017-2019. Goals of the ESOP were only financial, but they were simplified. According to the ESOP assumptions, the company will generate aggregated net earnings of 71.1 million PLN and aggregated gross revenues of 126.4 million PLN in the period 2017-2019. Again, the ESOP will be diminished by $10 \%$ of every $5 \%$ of the value of the objective that has not been met. The value of the ESOP as of 30 June 2020 was 31.75 million PLN, a 54-times increase compared to the 2014-2016 ESOP.

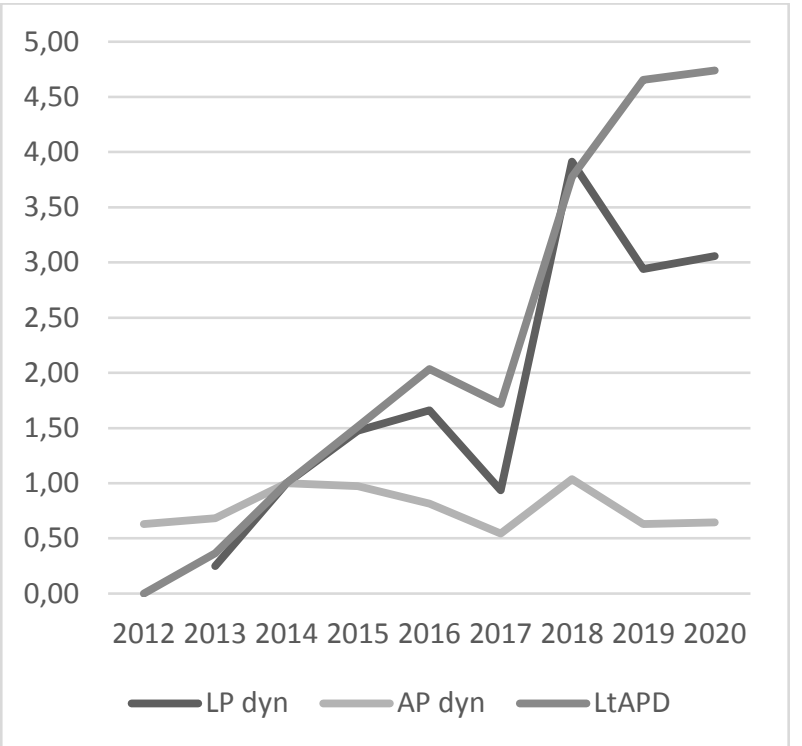

Fig.7: LP and AP dynamics in 11bit Studios. Note. 11bit Studios' 2010-2020 Financial Statements [35].

In the case of 11 bit Studios, LP grew by more than $300 \%$, and AP almost halved. This resulted in a very high value of LtAPD of nearly 5 . Similarly, to $\mathrm{CD}$ Projekt, this difference between the two types of productivities leads to the conclusion that the ESOP could have affected employees` motivation and resulted in higher labor productivity

\subsection{Ten Square Games}

Ten Square Games is a Wroclaw-based studio that specializes in mobile free-to-play games, with more than 200 games published since 2011. Its bestselling product, award-winning free-to-play game Fishing Clash, was released in 2016. It surpassed annual 100 million EUR revenue mark in 2020.The company has been publicly listed since 11 May 2018. Its games at the time of IPO had been already downloaded more than 280 million times. Studio's productions fall into three categories of products: (i) Evergreen - games with extensive gameplay environment facilitating in-game collaboration and competition with long lifetime (5 years+) that monetize through in-application purchases, (ii) Game Factory - casual games with simple gameplay that monetize through advertisement, (iii) Legacy - candidates for Evergreen that did not reach expected KPIs.

Ten Square Games' ESOP of 2018 [Resolution No 3 of Shareholders' Meeting of 15 March 2018 described in detail in the company's prospectus pp. 71, 141-143] [36] was dedicated to key employees and contractors of the capital group. The ESOP was later modified in 2019 [Resolution No 8 of Shareholders' Meeting of 14 January 2019] [37], and finallyfinancial goals were set at 2018 EBITDA of 26 million PLN, 2019 EBITDA of 31.5 million and 2020 EBITDA of 35 million PLN. The company offered to ESOP participants 101,850 new shares (1.4\% of the new shares). In the event of failing to reach the EBITDA target in one year, the ESOP still could be granted if the aggregated EBITDA for a two- or three-year period was reached. New shares would be distributed in three tranches - no earlier than 1 July 2020, no earlier than 1 January 2021, and no earlier than 1 September 2021. The supervisory board was entrusted with the task of selecting ESOP participants. On 21 April 2021, the supervisory board decided on the 2021 and 2022 EBITDA goals of 248.8 million PLN and 251.3 million PLN, respectively. During 2018-2020, the supervisory board undertook numerous resolutions, and it allocated 81,612 shares. The ESOP cost associated with those 81,612 shares was estimated at 3.6 million PLN. For the sake of clarity, the costs of the ESOP itself will be excluded from the EBITDA calculation. 


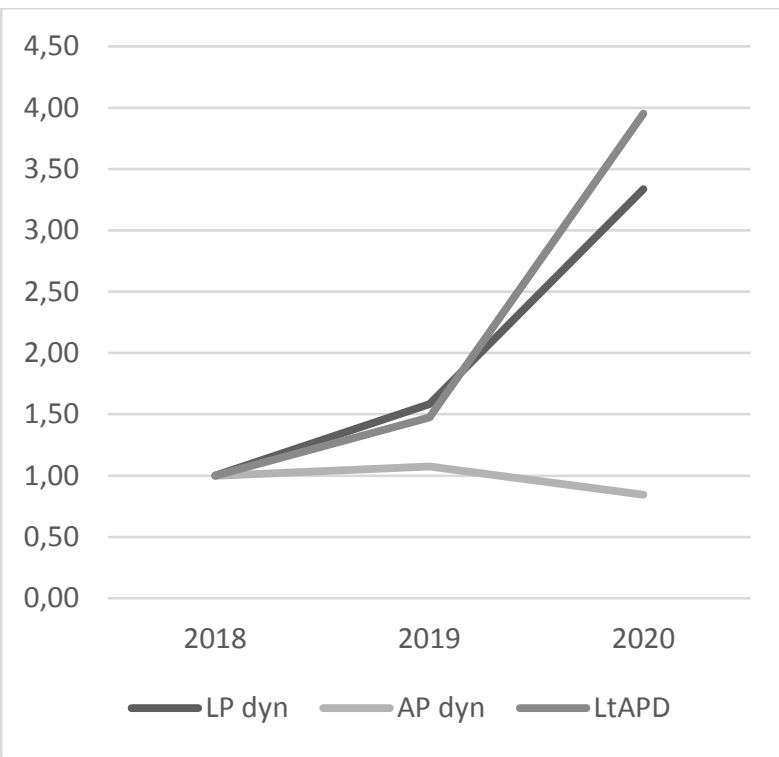

Fig.8: LP and AP dynamics in Ten Square Games. Note. Ten Square Games' Financial Statement [38].

The relatively shorter ESOP, compared to previous two, maintained a similar pattern of growing LP and falling AP. LP increased more than three times, whereas AP fell but not significantly $(15,6 \%)$. This case supports conclusions drawn previously for CD Projekt and 11 bit Studios - that is of (i) significantly rising LP, (ii) rising LtAPD, (iii) stabilizing or falling AP as company tends to keep cash for hard times after a successful game launch. As ESOP affects mainly employee's motivation, it can affect only LP and not AP. It is visible in the case of Ten Square Games. Successful Fishing Clash global launch in 2016 proved, that from financial perspective game concept works. In the following years game needed not only employee attention to maintain its KPIs, but also their true involvement to develop a series of updates and enhancements to the product, which made it one of the top-grossing games in 2020.

\subsection{Games}

CI Games (formerly known as City Interactive) was founded in 2002 in Warsaw and has been a publicly listed company since 2007. It is best known for tactical shooter AAA trilogy Sniper: Ghost Warrior released on 19 June 2010, 12 March 2013, and 25 April 2017. CI Games' ESOP of 2015 [Resolution No 17/2015 of the Shareholders' Meeting of 28 April 2015] [39] was directed to the management board members and other key employees and company contractors involved in the production of Sniper: Ghost Warrior 3. All tasks and responsibilities connected with the ESOP were entrusted to the supervisory board, which in
2017 distributed new shares. Consequently, the company has issued 920,000 new shares valued at 0.7 PLN each. The market value of CI Games shares in March 2017 was at historic highs of 2.5 PLN per share, so the ESOP was offering a $72 \%$ discount from the market price. As Sniper: Ghost Warrior 3 sales performance turned out to be short of the company's expectations, no more shares for this ESOP were issued. Over the next three years, the company conducted significant reorganization and lay-offs, and its shares were oscillating around 1 PLN per share.

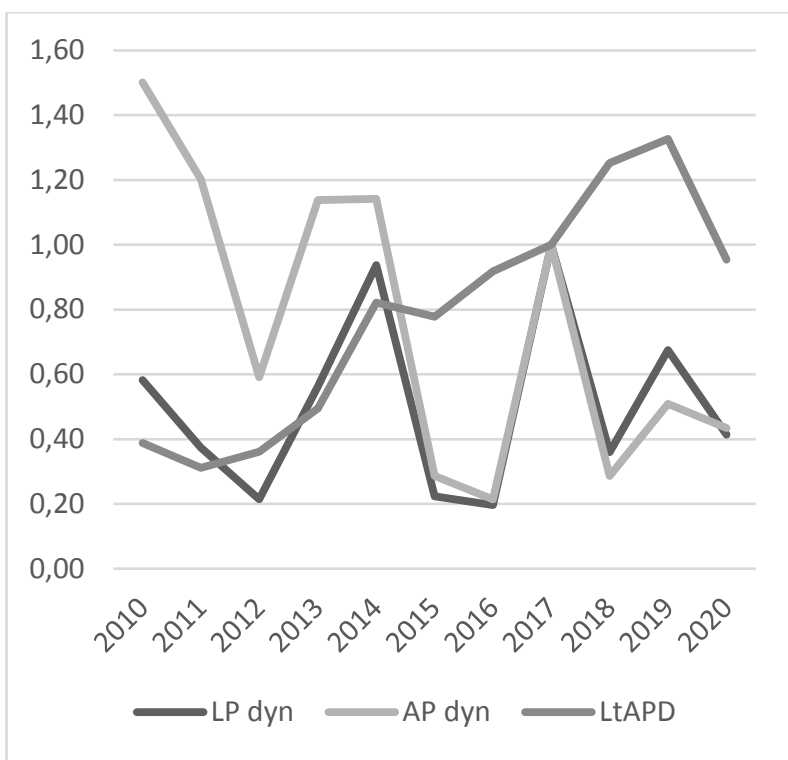

Fig.9: LP and AP dynamics in CI Games. Note. CI Games' Financial Statements [40].

In the case of CI Games, both LP and AP fell after the introduction of the ESOP. Although the AP decrease was stronger, resulting in $>1$ LtAPD during the first 2 years, comparison with $C D$ Projekt, 11bit Studios and Ten Square Games allows to conclude that the ESOP in CI Games most probably did not affect employee motivation.

\subsection{BoomBit}

BoomBit was established as mobile game developer in 2012 in UK. Presently the company is headquartered in Gdansk and its shares have been traded on the WSE since May 2019. It is best known for games such as Tiny Gladiators, Build a Bridge!, and Dancing Line.

BoomBit's ESOPs of 2018 and 2019 were directed only to two special persons [Resolution No 10 of Shareholders' Meeting of 7 August 2018 and Resolution No 6 of Shareholders' Meeting of 21 February 2019, both described in the company's 
prospectus, pp. 63-64, 311-314]. [41]. The first person, on account of his at least 3-year business intelligence and user acquisition services, was awarded warrants for new shares valued via the Black-Scholes formula at 1.67 million PLN, and the second person, on account of their management board membership, received warrants valued in the same way at 2.22 million PLN. The amounts of 1.67 million PLN and 2.22 million PLN are presented as the cost of salaries over the three years (2019-2021).

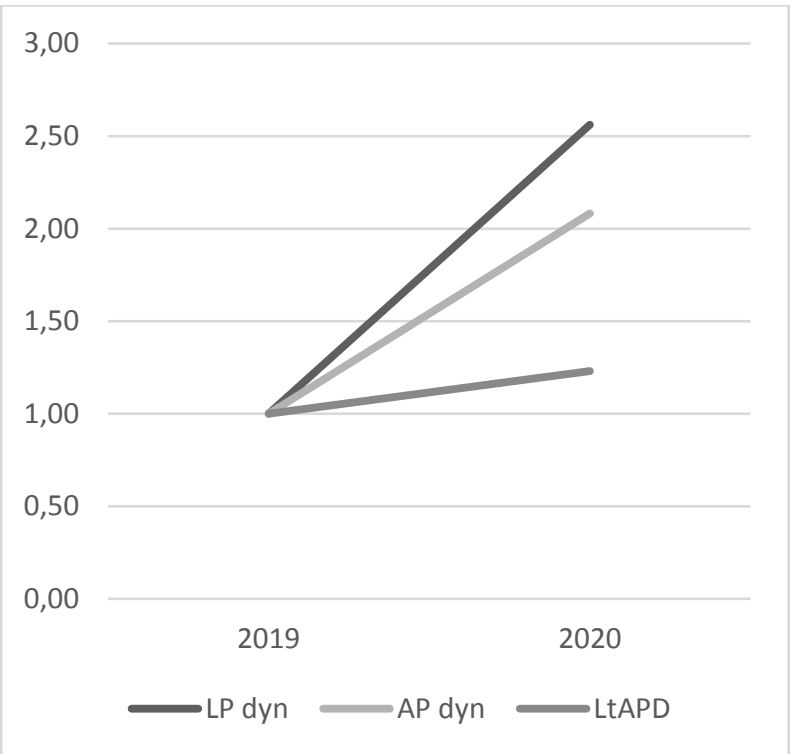

Fig.10: LP and AP dynamics in BoomBit. Note. BoomBit's Financial Statements [42].

BoomBit's ESOP is the most recently introduced one among all those analyzed in the research. However, in judging by the LP and AP dynamics, it seems that it has had no significant impact on motivation, as LP growth is accompanied by AP growth. This suggests that most probably it is not the ESOP that drove better company performance in 2020.
It can be noted that every company seems to have its own specific AP, which is mainly uncorrelated to ESOP. For example, in the case of CD Projekt, it is 0.72 (every 1 dollar of assets generates 72 cents of revenues). Then AP seems to decrease in years when there are costly development works on new games $(2013,2014)$ and increase when a new game is globally launched (2015). Then again, AP fell for a couple of years to low levels (2016-2019) and increased in 2020 when the new game, Cyberpunk 2077, was launched. In part, CD Projekt's low levels of AP can be explained by the fact that company is reluctant to paying dividends and is hoarding large sums of free cash. It is not atypical for gaming studios to keep earnings in the company because of the natural uncertainty that the next big game might not be a hit but a flop.

On the other hand, in the long term, LP rose significantly. In the first CD Projekt's ESOP, it started from the level of $342 \mathrm{k}$ USD and finished at 1.306 million USD, and in the second ESOP, it started at $711 \mathrm{k}$ USD and today is at 1.388 million.

Exactly the same pattern can be observed in the case of 11bit Studio. AP in 2012 and 2013, before the ESOP was introduced, was at 0.46 and 0.49 , respectively. For the next three years it rose to 0.60.7 and then fell to 0.46 and 0.47 in 2019 and 2020, despite the presence of the ESOP. One must notice, however, that LP rose very significantly during the ESOP, from 7.45k USD in 2013 to an average of $37,92 \mathrm{k}$ USD in 2014-2017, to reach its peak in 2018 of $117.1 \mathrm{k}$ USD. From shareholders perspective, ESOP introduction and consequent dilution of around $6 \%$ resulted in more than 15times growth of labor productivity. It is undoubtedly one of the most successful ESOP stories on WSE. 


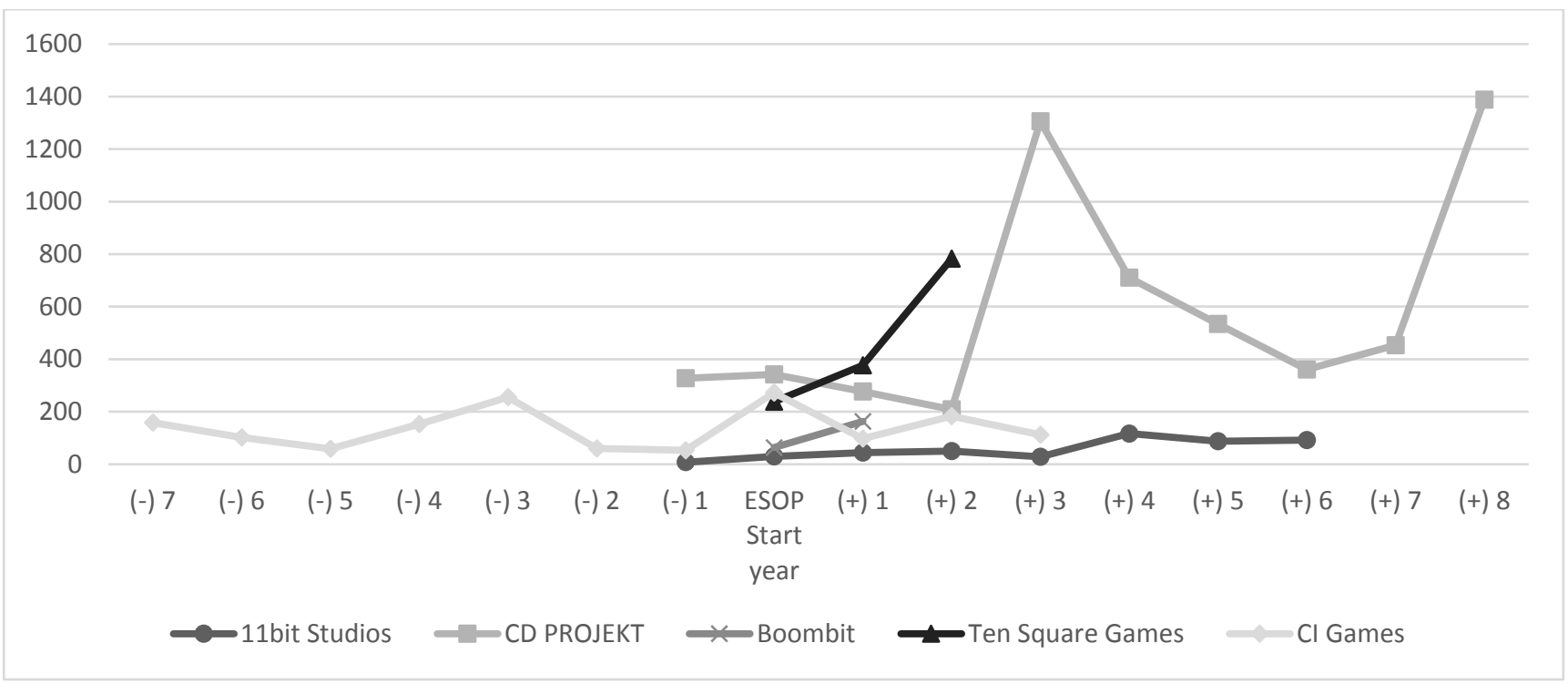

Fig.11: LP by company

In the case of BoomBit and Ten Square Games, it might be too early to assess the results of ESOP, but still Ten Square Games LP has more than tripled in three years since the company listing on the Stock Exchange and the introduction of the ESOP. On the other hand, BoomBit used its ESOP as a part of remuneration for two key individuals in the areas of business intelligence/user acquisition and corporate affairs, so one would be surprised if it had an effect on the LP. It seems more of a sophisticated form of management board remuneration. Both companies are in the mobile game sector, so it is to a degree surprising that the LP of Ten Square Games is 4.8-times that of BoomBit. Still, both ESOPs are completely different. The former is for a number of employees, while the latter is only for two individuals.

In the case of CI Games, its ESOP was introduced only to foster development and the performance of the third part of Sniper: Ghost Warrior trilogy and two future products, one of which even remained unnamed at the time of the ESOP's introduction. It evidently did not have any measurable positive effects on the company's performance. It seems from the size and design of this ESOP that it was meant not as a part of crosscompany employment strategy but as a potential bonus for its management board and top directors.

It can be noted that since the ESOP's introduction, LP in four out of five game development companies significantly improved, reaching levels of more than $400 \%$ of natural preESOP productivity. In this context, unsuccessful example of CI Games' ESOP is very interesting because it was distinct from all other successful ESOPs. Firstly, it was introduced one time at a mature stage when the company had already been listed for seven years. Secondly, it was relatively small even in its maximum size at its introduction. Thirdly, a large part of the ESOP (over one third) was dedicated to three persons on the management board. Fourthly, it was vague from its introduction, as the company could not name future games on which the ESOP would be relying. It is tempting to say that successful ESOPs need to be long-term ones, part of a company's culture, not one-time actions to generate extra bonuses for top management. 


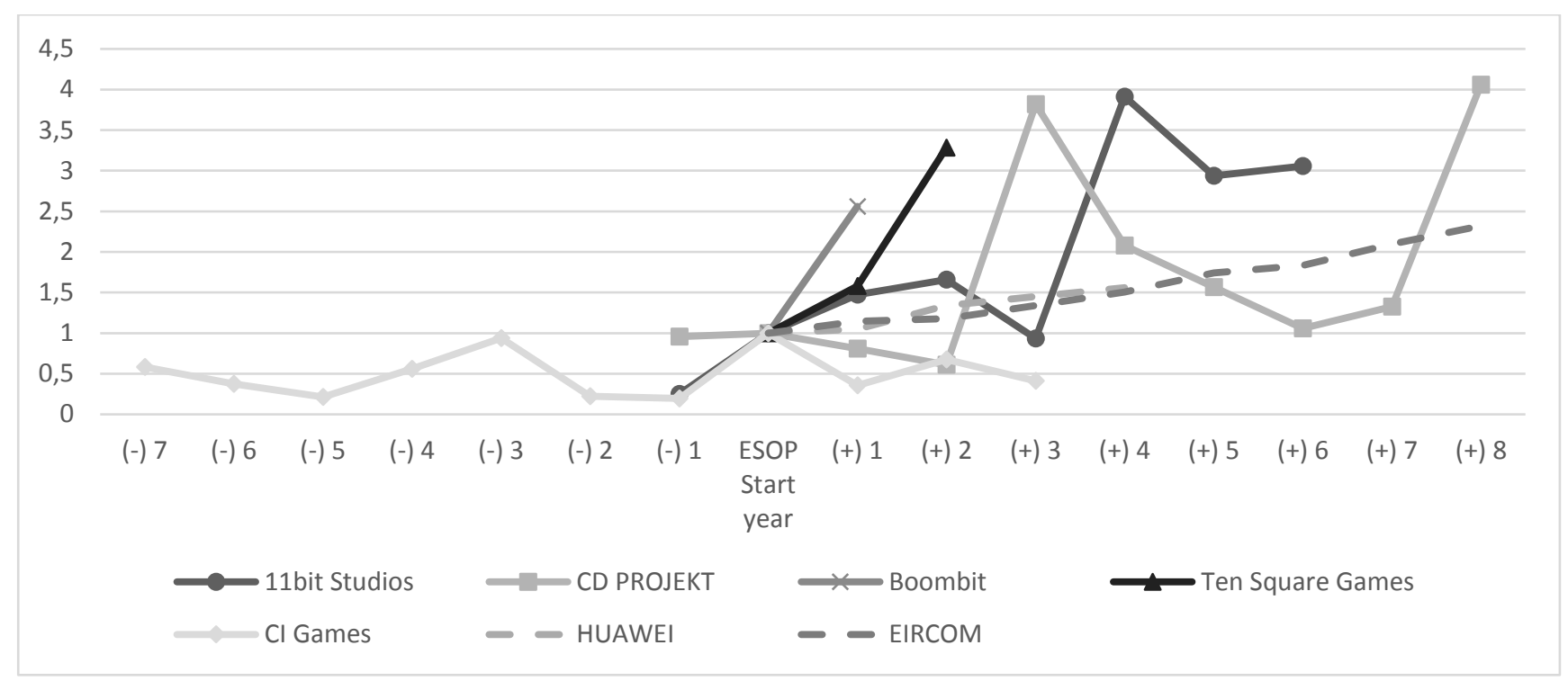

Fig.12: LP dynamics

\section{Discussion}

The literature review conducted allows to partially answer the first research question about the motivators for employees in the video game industry. The most important ones are (1) identification with the task, (2) employee participation and involvement and working with others, (3) good management, (4) a sense of belonging, (5) empowerment and responsibility, (6) equity, and (7) the financial stability of the company. This list, however, covers only the motivators for engineers. Further research should be conducted to cover other jobs important for the video game industry, like graphic artists, game designers, data analysts, and others.

To answer the second and the third research questions, results of the empirical research on ESOPs were used. The impact of ESOPs on the company performance was assessed using LtAPD.

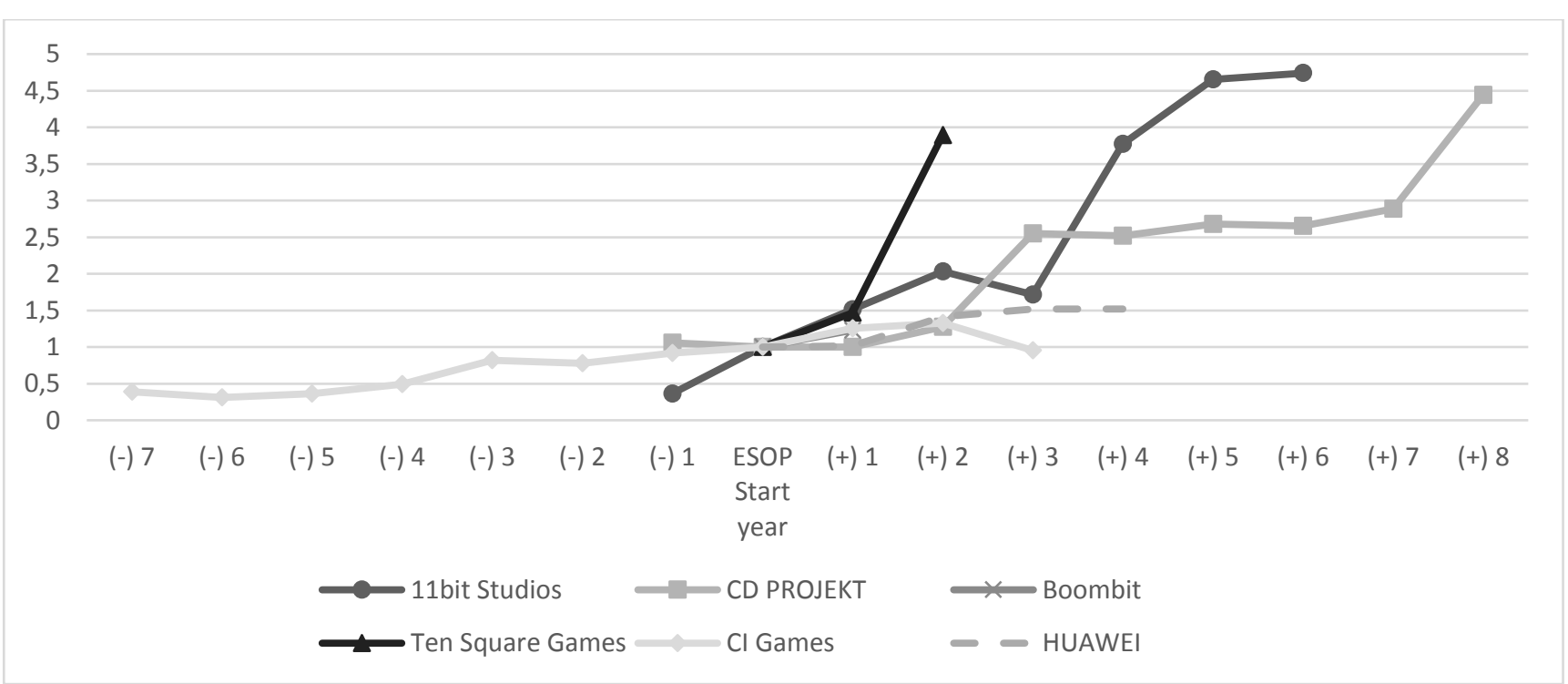

Fig.13: LtAPD comparison

Three companies (11bit Studios, CD Projekt, Ten Square Games) reached significantly higher LtAPD values than the other two (CI Games, BoomBit). CI Games was the only one to score a value below 1 . The three most successful companies noted much higher indicator values than Huawei [28], whose ESOP is an example of a wellimplemented EO plan. 
What could be the reason for such differences between LtAPD? As the comparison of the ESOPs structure shows, there was a significant differentiation between companies in the percentage of shares which were granted to ESOP participants. The Largest ESOP of CD Projekt (7.47\%) was 12-times the size of CI Games' ESOP $(0.61 \%)$. The size of the smallest ESOP to enjoy strong positive effect on LtAPD (Ten Square Games $4.77 \%$ ) was close to eight times bigger than CI Games' ESOP. As for shareholders, ESOP that introduces less than $1 \%$ of new shares is of considerably less importance from dilution perspective than ESOP that adds close to five (Ten Square Games), over six (11bit Studios) or even over seven percent (CD Projekt) of new shares.

Table 2. Percentage of shares for ESOP participants and effect on LtAPD

\begin{tabular}{lll}
\hline & $\%$ shares & LtAPD effect \\
\hline CD Projekt & $7.47 \%$ & strong positive \\
11bit Studios & $6.48 \%$ & strong positive \\
Ten Square Games & $4.77 \%$ & strong positive \\
BoomBit & $2.00 \%$ & positive \\
CI Games & $0.61 \%$ & neutral \\
\hline
\end{tabular}

Companies that had the best (strong positive LtAPD effect) LtAPD values, granted from $4.77 \%$ to $7.47 \%$ of shares to ESOP participants. The worst performing company (neutral LtAPD effect), CI Games, granted only $0.61 \%$ of shares. BoomBit (positive LtAPD) granted 2\%; but after only 2 years from the ESOP announcement, it is too early to assess its impact on LtAPD.

In view of the data presented, a conclusion can be drawn that ESOPs in video game companies can have a positive impact on LP. The relation between LP dynamics to AP dynamics grew to higher values in companies with ESOPs, which granted more than $4.77 \%$ of all shares of the company. The company which granted less than $1 \%$ of shares in the ESOP neither improved LP nor LtAPD.

Although the study did not cover any other coexisting factors of LP or AP, it is justified to conclude that for the video game companies listed on the WSE, the more shares that are granted in the ESOP, the stronger the positive effect on LP can be.

This is supported by the research of Gross [43], which suggests that there is a minimum employee participation level in the company shareholder structure which has to be reached for the ESOP to be successful.

With regard to the model of motivation for the video game industry presented in Fig. 5, it can be concluded that in video game companies, EO achieved by ESOPs improves productivity (LP). This supports the third and the second path of the model, which begin in Employee Ownership and lead to productivity through Psychological Ownership and Formal Ownership. Without further research it is impossible to conclude which one of them was the reason for the increased productivity in companies, which were subject of the research covered in this paper. This differentiation could shed more light on the results and arguably provide an additional dimension for LtAPD effect differentiation than the percent of shares. Also, the exploration of the first path could add required precision to the results, as currently there is no information whether there were changes in the job design implemented along with the ESOP. This could be achieved by the survey research in the video game companies, where the research tool would be the job diagnostic survey for data processing (JDS/DP) used by Cougar and Zawacki [8].

\section{Conclusions}

Results of the study can be applied in the video game companies that have a plan to introduce an ESOP. The main conclusion is that the percentage of the company's shares granted to ESOP participants has to be substantial enough to induce positive effects of EO. This does not mean that employees have to hold the majority of shares, but the volume should be high enough for the perceived ownership to emerge. In the case of the companies which were subject of the research, this meant from $4.77 \%$ to $7.47 \%$ of all shares.

Second conclusion is that ESOP need to be introduced at least one year before projected global launch of a new game. This time is needed for ESOP participants to see that goals for ESOP execution are achievable and effective workingplace measures can be taken to produce or fine-tune a game that will financially perform well. For ESOP to be successful, it needs to be firmly rooted in the company's culture.

Third conclusion is that a successful ESOP design requires company to prepare financial tools for ESOP participants to be able to execute ESOP. Typically, being awarded stock-exchange listed shares with a discount triggers personal income tax obligations that employees need to pay fast and in cash. Therefore, company needs to prepare hasslefree method for employee to execute ESOP (e.g. CD PROJEKT). 
Fourthly, proposed LtAPD measure has also very practical value, as it is an effective tool for shareholders, analysts and board members for assessment and comparison of ESOPs in a given industry. It links labor productivity dynamics (which is affected by ESOP) with asset productivity changes and gives answer to a question whether it was a good decision to introduce an ESOP.

\section{References:}

[1] Sobociński, M., Chłąd, M., \& Lewandowska, K., Aktualne problemy i wyzwania w branży gier wideo, Economics Studies, Vol.254, 2016, pp. 190-199.

[2] 2020 Essential Facts About Video Games Industry, Entertainment Software Association, 2020.

[3] Wijman, T., The World's 2.7 Billion Gamers Will Spend \$159.3 Billion on Games in 2020; The Market Will Surpass $\$ 200$ Billion by 2023, Newzoo, 2020. https://newzoo.com/insights/articles/newzoogames-market-numbers-revenues-andaudience-2020-2023/

[4] Video Games in the US-Employment Statistics 2003-2026, IBISWorld-Industry Market Research, Reports, and Statistics, 2020. https://www.ibisworld.com/industrystatistics/employment/video-games-unitedstates

[5] Dyer-Witheford, N., \& Sharman, Z., The Political Economy of Canada's Video and Computer Game Industry, Canadian Journal of Communication, Vol.30, No.2, 2005. https://doi.org/10.22230/cjc.2005v30n2a1575

[6] Rutkowski, E., Marszałkowski, J., \& Bidermann, S., The game industry of Poland, Polska Agencja Rozwoju Przedsiębiorczości, 2020.

[7] Beecham, S., Baddoo, N., Hall, T., Robinson, H., \& Sharp, H., Motivation in Software Engineering: A Systematic Literature Review, Information and Software Technology, Vol.50, No.9-10, 2008, pp. 860878. https://doi.org/10.1016/j.infsof.2007.09.004

[8] Sharp, H., Baddoo, N., Beecham, S., Hall, T., \& Robinson, H., Models of motivation in Software Engineering, Information and Software Technology, Vol.51, No.1, 2009, pp. 219-233.

https://doi.org/10.1016/j.infsof.2008.05.009
[9] Schmid, B., \& Adams, J., Motivation in Project Management: The Project Manager's Perspective. Project Management Journal, Vol.39, No.2, 2008, pp. 60-71. https://doi.org/10.1002/pmj.20042

[10] Project Management Institute, A Guide to the Project Management Body of Knowledge (PMBOK® $\quad$ Guide $) \quad\left(6^{\text {th }}\right.$ edition), Project Management Institute, 2017.

[11] Hackman, J., \& Oldham, G. R., Motivation Through the Design of Work: Test of a Theory, Organizational Behavior and Human Performance, Vol.16, No.2, 1976, pp. 250$279 . \quad$ https://doi.org/10.1016/00305073(76)90016-7

[12] Oldham, G. R., \& Hackman, J. R., Not What It Was and Not What It Will Be: The Future of Job Design Research, Journal of Organizational Behavior, Vol.31, No.2-3, 2010, pp. 463-479. https://doi.org/10.1002/job.678

[13] Couger, J. D., Zawacki, R. A., \& Oppermann, E. B., Motivation Levels of MIS Managers Versus Those of Their Employees. MIS Quarterly, Vol.3, No.3, 1979, p. 47. https://doi.org/10.2307/248788

[14] Couger, D. J., \& Zawacki, R. A., Motivating and Managing Computer Personnel (Business Data Processing) (1st ed.), Wiley, 1980.

[15] Pierce, J. L., Jussila, I., \& Cummings, A., Psychological Ownership Within the Job Design Context: Revision of the Job Characteristics Model, Journal of Organizational Behavior, Vol.30, No.4, 2009, pp. 477-496. https://doi.org/10.1002/job.550

[16] Pierce, J. L., Rubenfeld, S. A., \& Morgan, S., Employee Ownership: A Conceptual Model of Process and Effects, The Academy of Management Review, Vol.16, No.1, 1991, p. 121. https://doi.org/10.2307/258609

[17] Long, R. J., The Effects of Formal Employee Participation in Ownership and Decision Making on Perceived and Desired Patterns of Organizational Influence: A Longitudinal Study, Human Relations, Vol.34, No.10, 1981, pp. 847-876. https://doi.org/10.1177/001872678103401003

[18] Rosen, C., \& Quarrey, M., How Well Is Employee Ownership Working? Harvard Business Review, 1987. https://hbr.org/1987/09/how-well-is-employeeownership-working

[19] Hammer, T. H., \& Stern, R. N., Employee Ownership: Implications for the Organizational 
Distribution of Power, Academy of Management Journal, Vol.23, No.1, 1980, pp. 78-100. https://doi.org/10.2307/255497

[20] Blasi, J., Kruse, D., Sesil, J., \& Kroumova, M., An Assessment of Employee Ownership in the United States With Implications for the EU, The International Journal of Human Resource Management, Vol.14, No.6, 2003, pp. 893-919. https://doi.org/10.1080/0958519032000106137

[21] Christiansen, R. O., Impact of Employee Stock Ownership Plans on Employee Morale, American Journal of Small Business, Vol.5, No.1, 1980, pp. 22-30. https://doi.org/10.1177/104225878000500105

[22] Jones, D. C., \& Kato, T., The Scope, Nature, and Effects of Employee Stock Ownership Plans in Japan, Industrial and Labor Relations Review, Vol.46, No.2, 1993, p. 352. https://doi.org/10.2307/2524877

[23] Rosen, C., Employee Stock Ownership Plans: A New Way to Work, Business Horizons, Vol.26, No.5, 1983, pp. 48-54. https://doi.org/10.1016/0007-6813(83)90104-0

[24] Welch, J., Stock-Option Cultures: Employee Ownership in a High-Growth Software Company, Academy of Management Proceedings, Vol.2002, No.1, 2002, pp. H1H6. https://doi.org/10.5465/apbpp.2002.7516621

[25] Bryson, A., \& Freeman, R., Doing the right thing? Does Fair Share Capitalism Improve Workplace Performance?, Employment Relations Research Series, Vol.81, No.50, 2004.

[26] Bakan, I., Suseno, Y., Pinnington, A., \& Money, A., The Influence of Financial Participation and Participation in DecisionMaking on Employee Job Attitudes, The International Journal of Human Resource Management, Vol.15, No.3, 2004, pp. 587616.

https://doi.org/10.1080/09585192.2004.100576 54

[27] Livingston, D. T., \& Henry, J. B., The Effect of Employee Stock Ownership Plans on Corporate Profits. The Journal of Risk and Insurance, Vol.47, No.3, 1980, p. 491. https://doi.org/10.2307/252634

[28] Zhu, Z., Hoffmire, J., Hoffmire, J., \& Wang, F., Employee Stock Ownership Plans and Their Effect on Productivity: The Case of Huawei, International Journal of Business and Management Invention, Vol.2, No.8, 2013.
[29] McCarthy, D., \& Palcic, D., The Impact of Large-Scale Employee Share Ownership Plans on Labour Productivity: The Case of Eircom, The International Journal of Human Resource Management, Vol.23, No.17, 2012, pp. 3710-3724. https://doi.org/10.1080/09585192.2012.655762

[30] Treść uchwał podjętych na Nadzwyczajnym Walnym Zgromadzeniu Akcjonariuszy CD Projekt RED S.A. w dniu 16 grudnia $2011 \quad$ r., 2011. https://www.cdprojekt.com/pl/wpcontent/uploads-pl/2016/03/2011_73_zal.pdf

[31] Treść uchwał podjętych na Zwyczajnym Walnym Zgromadzeniu Akcjonariuszy CD Projekt S.A. w dniu 24 maja 2016 r., 2016. https://www.cdprojekt.com/pl/wpcontent/uploads-pl/2016/05/rb_18-2016zalacznik.pdf

[32] Roczne, CD Projekt, 2020. https://www.cdprojekt.com/p1/typ-informacjiprasowej/year/?typ-informacji-prasowej=year

[33] Treść uchwał podjętych przez Zwyczajne Walne Zgromadzenie Akcjonariuszy spółki 11 bit studios Spółka Akcyjna w dniu 27 czerwca $2014 \quad$ roku, 2014. https://irhub.11bitstudios.com/message/attachm ent?id=20140630_153030_0000067092\&fid=1 $\& \mathrm{t}=\mathrm{ebi}$

[34] REPERTORIUM A $n r$ 3343/2017, 2017. https://irhub.11bitstudios.com/message/attachm ent?id=20170510_164558_0000098297\&fid=1 $\& \mathrm{t}=\mathrm{espi}$

[35] Raporty, 11 bit studios-Relacje Inwestorskie, 2020. https://ir.11bitstudios.com/raporty

[36] Prospekt Emisyjny Ten Square Games S.A., Ten Square Games S.A., 2018. https://tensquaregames.com/wpcontent/uploads/2021/02/2018-04-10-TenSquare-Games_prospekt-emisyjny_final-3skompresowany.pdf

[37] Uchwała nr $8 \mathrm{z}$ dnia 14 stycznia 2019 r. Nadzwyczajnego Walnego Zgromadzenia Ten Square Games Spółka Akcyjna z siedzibą we Wrocławiu w sprawie zmiany Uchwały nr 3 Nadzwyczajnego Walnego Zgromadzenia Ten Square Games S.A. z siedzibą we Wrocławiu z dnia 15 marca 2018 r., 2019, Ten Square Games S.A. http://biznes.pap.pl/espi/pl/reports/view/attach ment/Tresc uchwal podjetych NZW 14.01.19.pdf,

[38] Archiwa: Okresowe, Ten Square Games One of the Biggest Mobile Games 
Development Company in Poland, 2020. https://tensquaregames.com/pl/report-

category/okresowe/

[39] UCHWAŁY PODJĘTE PRZEZ ZWYCZAJNE WALNE ZGROMADZENIE AKCJONARIUSZY CI GAMES SPÓŁKI AKCYJNEJ Z SIEDZIBĄ W WARSZAWIE W DNIU 28 KWIETNIA 2015 ROKU, 2016. https://cigames.com/wpcontent/uploads/2016/04/Tresc_uchwal_podjet ych_przez_Zwyczajne_Walne_Zgromadzenie_ Akcjonariuszy_Spolki_CI_Games_S.A._w_dni u_28.4.2015_r..pdf

[40] Relacje inwestorskie, CI Games, 2020. https://cigames.com/relacje-

investorskie/\#periodic

[41] Prospekt Emisyjny, BoomBit S.A., 2019. https://boombit.com/app/uploads/2019/04/Pros pekt-emisyjny.pdf

[42] Raporty okresowe, BoomBit, 2021, April 23. https://boombit.com/pl/ir/raporty-okresowe/

[43] Gross, B. The New Math of Ownership, Harvard Business Review, 1998. https://hbr.org/1998/11/the-new-math-ofownership

\section{Contribution of Individual Authors to the Creation of a Scientific Article} (Ghostwriting Policy)

Rafał Łabędzki was responsible for the literature review, research model, research method, empirical research and results, discussion and conclusions.

Przemysław Gadomski was responsible for the research method, empirical research and results, discussion and conclusions.

Paweł Multaniak was responsible for the empirical research.

Sources of Funding for Research Presented in a Scientific Article or Scientific Article Itself

SGH Warsaw School of Economics funded proofreading and publication.

Creative Commons Attribution License 4.0 (Attribution 4.0 International, CC BY 4.0)

This article is published under the terms of the Creative Commons Attribution License 4.0

https://creativecommons.org/licenses/by/4.0/deed.e $\underline{\text { n US }}$ 